\title{
Semiotic Compression of Culturonyms in English and German Versions of M. Bulgakov's the Master and Margarita
}

\author{
Alexandra Milostivaya \\ PhD, North-Caucasus Federal University \\ Email: xysha@mail.ru
}

Tatiana Marchenko

PhD, North-Caucasus Federal University

Email: tatiana-marchenko-25@yandex.ru

\section{Doi:10.5901/mjss.2015.v6n3s2p435}

\begin{abstract}
The article deals with the study of semiotic compression of culturonyms "Rudeness in phone conversations", "Queue" and "Solovki" presented in English and German translations of The Master and Margarita after M. Bulgakov. The aim of the study is to specify the compression of semiotic culturonym representations in translation, i.e. semiotic compression that entails seme reduction of a target language unit as compared with the source language unit. The study has revealed that the process is preconditioned by two relevant reasons. Firstly, the translator as a representative of a foreign linguoculture as regards the author of the source text (ST) can fail to perceive the connotations conveyed by culturonyms; secondly, he can adapt ST so that it could be comprehensible for an "average" recipient of the target text (TT) who lacks intercultural communicative competence. The latter results in the fact that TT does not produce the implied communicative effect. The main research method employed in the study is the comparative analysis of English and German translated versions with the ST.
\end{abstract}

Keywords: English and German translations of The Master and Margarita after M. Bulgakov, semiotic compression, culturonym.

\section{Introduction}

The reflection of Homo Loquens phenomenon has been in the focus of recent studies in modern linguistics. The topic has been examined not only within the framework of linguo-culture studies but also in translatology, the field in which primary importance is assigned to anthropocentric and culture-centric aspects. It is only natural that this approach results in the surge of interest to contrastive studies of different linguo-cultures. The article explores the compression of culturonyms actualized in English and German translations of M. Bulgakov's The Master and Margarita.

\section{Literature Review}

The culture of any people is reflected in language (Iser, 1996; Deutscher, 2010; Lambert, 2006; Sturge, 2009) and since the culture of any people has its own ethnic flavor the lexemes that nominate its specific character are unique in the perspective of translation (Milostivaya, Marchenko, 2013; Milostivaya, Marchenko, 2014; Zauberga, 2005). In our article we assume that "translating can now be envisaged as the process which transforms one semiotic entity into another" (Hatim \& Mason, 1990, p. 105).

The translation process is not only about rendering source language $(\mathrm{SL})$ linguoculture semiotic codes into target language (TL). It is supposed to preserve ST ethnic flavor in TT. A great deal of words conveys connotative meanings which are not codified in dictionary entries. Still native speakers comprehend them and display particular feelings and emotions. These lexical units are closely associated with specific cultural features and everyday life of native speakers. However, one can not translate them into a different language automatically and quite often encounters challenges. We call such words culturonyms. In our article we proceed from V. Kabakchi's view and refer to a "culturonym" to denote "all (relevant for a particular nation) elements of terrestrial civilization' (Kabakchi, 2001, pp. 418-419). A culturonym as compared with a word has a more complex structure: the plane of content falls into purely linguistic meaning and cultural meaning. It conveys connotative meaning and "stays as long as the ideological context that has given rise to it" (Vorobjev, 1997, p. 52). 
In the process of translation semiotic representations of culturonyms can undergo compression, i.e. the semiotic compression through the reduction of semes within a unit of translation as compared to the source. We presume two reasons underlying the above mentioned process.

Firstly, being a representative of a foreign linguoculture as regards ST a translator can fail to decode connotations conveyed by culturonyms; secondly, he can opt to modify ST in line with comprehension of an "average" TT recipient who has poor intercultural communicative competence. It could lead to the case that TT does not produce the implied communicative effect. Owing to this fact TT does not provoke 'the required communicative effect as it makes the reader tense about notions of objects and phenomena which are uncommon, strange and probably alien to his culture' (Garbovskiy, 2004, p. 403).

The article explores the compression of such culturonyms as "Rudeness in phone conversations", "Queue" and "Solovki" that are actualized in English and German translations of M. Bulgakov's The Master and Margarita. The choice of the novel for the study is deliberate. The Master and Margarita by M. Bulgakov is a well-known novel considered to be a distinguished piece of classical Russian literature. M. Bulgakov refers to satire while depicting life in Moscow of the 2030s. The author portrays rascals and scoundrels of all stripes. After the revolution Soviet society found itself in spiritual and culture self-isolation. In the leaders' opinion, lofty ideas were supposed to re-educate people and turn them into honest and just constructors of a "new society". Mass-media extolled feats of labor and commitment of Soviet people to the party and society. But an "ideal Soviet man" remained on paper, in reports and slogans. In real people lived in fear of intolerance to a different opinion on the part of authorities. In order to praise bolshevism whole layers of world history and the vivid Russian language were substituted by vacuous political twaddle. Culturonyms employed in M. Bulgakov's novel reveal the political temperature of the depicted epoch. Their peculiarities from traslatological point of view present special interest since, on the one hand, the author's mentality and the mentality of his characters and, on the other hand, the translator's and TT reader's world outlook, are totally different, and it leads to challenges in decoding axiological shades of culturonyms which nominate the life of Soviet people in 1920-30s.

The article presents the analysis of several excerpts from M. Bulgakov's The Master and Margarita and its translated versions in English (by Michael Glenny in 1967) and in German (by German translators Thomas Reschke in 1968). These translations of M. Bulgakov's novel were republished many times and turned to be classical versions. But we also set out to analyze some new, still not so widely known, translated versions of the novel by Hugh Aplin (2008) and Eric Boerner (2012).

\section{Methodology}

The general methodology of the study rests on the concept of dialectical unity of language and culture. We adhere to the anthropocentrism principle which assigns primary importance to the "study of how a man "appropriates" the language, uses the language for cognitive and communicative purpose and thus influences its functioning in different spheres of linguo-society" (Andreyeva, 2009, p. 4). The main research method employed in the article is the comparative analysis of English and German translated versions with the source text. It reveals the similarities and differences of ST and TT or TTs, and makes it possible to specify the appropriateness and necessity of the digressions made. In particular, the focus of the study is the semiotic analysis of culturonyms in ST and TT. It reveals specific connotations related to the description of culture words typical of socialism epoch and is addressed to while interpreting linguocultural lacunas. Our conclusions concerning translation equivalence at semiotic compression of culturonyms in M. Bulgakov's novel The Master and Margarita by English and German translators are verified through the reference to:

- verifying quotations from other passages of M. Bulgakov's The Master and Margarita;

- informants that are representatives of Soviet communication culture of the period in question;

- films that cover the early-Soviet period depicted in Bulgakov's novel.

\section{Analysis}

The characteristics of such a specific feature of Soviet national character as rudeness in phone conversations, the one that often seems striking for foreigners, may serve as a perfect illustration of semiotic compression in culturonyms. Yu. Prokhorov and I. Sternin emphasize that a Soviet man often displays contempt for his interlocutor. They note his rough tone in phone conversation and the possibility of categorical refusal without any explanations (Prohorov \& Sternin, 2007, p. 193). Such cases are not infrequent in present-day Russian society. So this topic is in the focus of a report by Tver News Agency: 
I just want to raise the issue of rudeness in telephone conversation and get some information from lawyers and experienced people concerning what one can do in case someone on the other end of the line does not pay attention, is reluctant to do anything and even rude.

A new example. One of these days the regional radio aired a programme with a lady working in cadastral department. The contact number was given. I am calling. A young lady picks up the receiver and says:

- Ask me your question first.

I ask her:

- Who are you?

The answer is:

- Does it make any difference. You either ask your question or disengage the line.

Under such pressure the question slipped my mind.

I tell her:

- But you have not introduced yourself!

The answer comes with lightning speed:

You too! - and hung up the receiver. (Tver News Agency, 2011)

In his novel M. Bulgakov depicts a similar conversation between variety manager Varenukha and a man from Woland's retinue. This is how rude telephone conversation in Russian is rendered in English and German translated versions:

- Da! - kriknul Varenuha.

- Ivan Savel'evich? - osvedomilas' trubka protivnym gnusavym golosom.

- Ego netu v teatre! - kriknul bylo Varenuha, no trubka totchas ego perebyla:

- Ne valjajte duraka, Ivan Savel'evich, a slushajte. Telegrammy jeti nikuda ne nosite i nikomu ne pokazyvajte.

(Bulgakov, 1988, p. 112)

'Yes?' he shouted.

'Ivan Savyelich?' enquired the receiver in a odious nasal voice.

'He's not in the theatre!' Varenukha was just about to shout, but the telephone cut him short:

'Don't play the fool, Ivan Savyelich, and listen. You are not to take those telegrams anywhere to show them to anybody.'

(Bulgakov, 2004, p. 131)

"Yes!" cried Varenukha.

"Ivan Savyelich?" the receiver enquired in the most repellent nasal voice.

"He's not in the theatre!" Varenukha was about to cry, but the receiver immediately interrupted him:

"Don't act the fool, Ivan Savyelich, just listen. Don't take those telegrams anywhere and don't show them to anyone."

(Bulgakov, 2008, p. 111)

"Hallo!" schrie Warenucha.

"Iwan Saweljewitsch?" fragte der Hörer mit scheußlicher Näselstimme.

"Ist nicht im Theater!", wollte Warenucha rufen, doch der Hörer schrie sofort:

"Spielen sie nicht den Dummkopf, Iwan Saweljewitsch, und hören Sie zu. Sie werden die Telegramme nirgendwo hinbringen und keinem zeigen." (Bulgakow, 2008,p. 140)

"Ja!" schrie Warenucha.

"Iwan Saweljewitsch?" erkundigte sich der Hörer mit einer widerwärtig näselnden Stimme.

"Er ist nicht im Theater!", hätte Warenucha geschrieen, doch der Hörer unterbrach ihn sofort:

"Spielen sie nicht den Trottel, Iwan Saweljewitsch, sondern hören Sie zu. Die Telegramme werden Sie nirgendwohin bringen und niemandem zeigen." (Bulgakow, 2012, p. 120)

In translation versions given above we set off two remarks containing rude words in bold type. In the first case a shade of rudeness in telephone conversation is rendered by a colloquial negation 'netu' ('no'). As regards the passage in question neither English nor German translators managed to adequately decode rudeness in speech that represents a specific semiotic culture code typical of interpersonal communication between Soviet people. In the second case this meaning is rendered in TLs by means of equivalents to an idiom 'ne valjajte duraka' ('don't play the fool'). Both in English and in German there are set equivalents of the idiom ('don't play the fool / don't act the fool', 'Spielen sie nicht den Dummkopf /Spielen sie nicht den Trottel'). But it is evident that the semiotic compression does take place in rendering the culturonym "Rudeness in phone conversations". It results in reduction of semes in TT that convey the information about the routine character of such social practice in everyday communication in former USSR.

The citizens of former Soviet Union, including the ones that witnessed the period depicted in The Master and Margarita, experienced stock-out and queues as immanent everyday life phenomena. The fact that west-European cultures have never observed such socio-economic phenomena challenges the translation of culturonyms that denote them: 
"Zapis' v ochered' na bumagu u Poklevkinoj». (Bulgakov, 1988, p. 58) - 'Waiting List for Paper - Apply to Poklevkina'. (Bulgakov, 2004, p.54) - "Registration for Waiting List for Paper at Poklyovkina's" (Bulgakov, 2008, p. 69) - "Eintragung in die Papierzuteilungsliste bei Pokljowkina". (Bulgakow, 2008, p. 71) - "Eintrag in die Warteschlange für Papier bei Pokljowkina". (Bulgakow, 2012, p. 58)

The abovementioned notice on the door of one of the rooms in the House of Griboyedov is translated by $T$. Reschke into German by means of reduction the seme "Queue" (the German composite 'Papierzuteilungsliste' literally means "a list of persons which are about to be given paper"). Thus at least one seme is omitted and the phenomenon is deprived of a special sociocultural characteristic. Another German translator, E. Boener, on the contrary, conveys this culturonym in a communicatively adequate way. He opts for the equivalent 'Warteschlange' which implies the idea of physical presence of a person in a queue.

The English translators M. Glenny and H. Aplin opted for a different variant in this case. He employed the strategy of descriptive translation and explicitly decoded the culture word. This is how we come across an equivalent to a Soviet cultureme 'Waiting List for Paper'/ 'Registration for Waiting List for Paper' in an English version of The Master and Margarita. They render the denotative content of ST correctly but do not convey any negative connotations associated with a queue in Soviet discourse. Both English translators employed semiotic compression of culturonyms in the passage under consideration. So the fact of personal attendance and standing in a queue is eliminated. At this point one essential detail should be noted. There are passages in M. Bulgakov's The Master and Margarita that verify that it was particularly standing in a queue that was an immanent attribute of getting material benefits in Soviet society.

At the head of the longest queue, which started downstairs at the porter's desk, was a door under constant siege labelled 'Housing Problem' (Bulgakov, 2004, p. 69)

Semiotic compression of culturonym 'Solovki' can be illustrated with the example given below. The period depicted in The Master and Margarita is one of the most tragic and brutal in Soviet history. The 1930s witnessed Stalin's repressions at their height. They concerned most people in the USSR. But official Soviet propaganda reported great achievements in five-year plans and triumphs in socialism construction. So the repressions were only whispered, mostly in backroom conversations. The atmosphere of fear, suspiciousness and spy fever reigned in the Soviet society of that time. The following quotation taken from an Oscar awarded Russian-French movie Burnt by the Sun illustrates the idea:

- A dacha dweller: My name is Vsevolod Konstantinovich. Have you called for Dmitry Andreyevich? May I ask you what agency can send such a car?

- A driver (GPU official (GPU - Government Political Board): Regional philharmonic society (Burnt by the sun, 1994)

(Translated by us - A.M., T.M.).

The above mentioned passage shows that in 1930s in the USSR it was not common practice to explicitly inform about somebody's arrest.

Now we take a close look at the way M. Bulgakov depicted such controversial mood in Soviet society and analyze the peculiarities of semiotic compression of culturonyms in English and German translation of the passage given below:

Vzjat' by jetogo Kanta, da za takie dokazatel'stva goda na tri v Solovki! - sovershenno neozhidanno buhnul Ivan Nikolaevich! (Bulgakov, 1998, p. 17) - 'Kant ought to be arrested and given three years in Solovki asylum for that "proof" of his!' Ivan Nikolayich burst out completely unexpectedly. (Bulgakov, 2004, p. 19) -"This Kant should be taken and sent to Solovki for two or three years for such proofs!" (Bulgakov, 2008, p. 11) - "Für solche Beweise müßte man den Kant drei Jahre nach Solowki verbannen!" stie $\beta$ Besdomny überraschend hervor. (Bulgakow, 2008, p. 19) "Man sollte diesen Kant nehmen und und wegen dieser Beweise für drei Jahre nach Solowki!", platzte völlig unerwartet Iwan Nikolajewitsch heraus. (Bulgakow, 2012, p. 12)

Our observations of the passage suggest that Bulgakov's character Ivan Bezdomny is extremely suspicious of his surroundings. He displays vigilance even to I. Kant, the outstanding German philosopher who lived more than a century ago. Along with vigilance I. Bezdomny displays caution in his speech: he does not suggest arresting I. Kant but merely makes a hint that it is better to treat the peace-breaker in accord with Zeitgeist.

Thus, translators are challenged with the task that, on the one hand, they have to render factual information implicitly presented by Bulgakov's character - the way how I. Kant should be treated, and on the other hand, translators are expected to preserve the taboo manner of conversations about arrests in Soviet society of the 1930s. Rendering factual information in the passage is complicated for the reason it could be challenging for a foreign recipient to interpret 
the toponym 'Solovki'. It could require some extra efforts to get the idea whether it is just a name of the city, some other settlement or an island. Even more challenging seems to decode the piece of information about Solovki as a geographical area located in the north and the one that in Soviet times traditionally housed political prisoners in exile.

Taking it into account it should be noted that the semiotic code of a Soviet cultureme 'Solovki' is adequately rendered in T. Reschke's German translation as it contains explicit information about the purpose of I. Kant's stay in Solovki, i.e. the exile. Verbally the information is expressed by the verb 'verbannen' that compensates culture-semiotic entropy in communication. In E. Boener's version this entropy is not clarified as the implication of the author concerning what Kant is going to do in Solovki does not seem clear: "Man sollte diesen Kant nehmen und und wegen dieser Beweise für drei Jahre nach Solowki!". E. Boener employs a neutral verb 'nehmen' which is not associated with thde concept of political repressions.

In our own opinion it seems convincing enough that the M. Glenny's English translation of the passage reveals excessive, unreasonable adaptation aimed at greater transparency of implicit meaning. It is achieved through the reference to the verb 'to arrest' that was intentionally omitted in ST. So it is evident that the passage demonstrates the case of semiotic compression of a culturonym. The translator fails to take into account the fact that the topic of arrests in Soviet society of that time was a taboo in interpersonal communication of its members. On the contrary, $\mathrm{H}$. Aplin translates the passage under consideration in a more communicatively adequate way as regards culturonyms. The translator focuses on conveying the denotative aspect in the text 'should be taken and sent to Solovki for two or three years' while the connotations connected with hints about terrific camp for those in political exile in Solovki are expressed in a translation commentary to the text. It seems to be an appropriate way to express the antinomy of overall fear of repressions in the Soviet Union of the 1920-30s on the one hand, and tabooing public discussion of those repressions at the same time on the other hand.

\section{Conclusion}

Translations of M. Bulgakov's The Master and Margarita can experience compression of semiotic culturonym representations, i.e. semiotic compression that is actualized as seme reduction of a target language unit as compared with the source language unit. The analysis has traced two relevant reasons for the process. Firstly, as a representative of a foreign linguoculture as regards the author of the ST a translator can fail to perceive connotations conveyed by culturonyms; secondly, he can adapt ST in order to make it more comprehensible for an "average" recipient of TT as the latter is likely to have poor intercultural communicative competence or none at all. The text can be deprived of the intended communicative effect and make the reader feel tense about notions of objects and phenomena which are uncommon, strange and probably alien to his culture. The study proves that semiotic compression of culturonyms in Russian-German translation is an essential prerequisite to produce communicatively equivalent TT tuned in line with the mentality of target culture.

\section{Findings}

The conclusions of the study reveal that the mentality of a people and the peculiarities of its outlook are markedly reflected in literature. The language preserves some linguistic signs that denote specific culture realia and provoke particular feelings and associations in native speakers. Such signs are culturonyms.

The translation process is not only about rendering these words automatically but it is also about preserving semiotic peculiarities of SL culture. But total matches are rather rare. Generally with the aim to enhance translation equivalence a translator modifies semiotic meaning of a ST culturonym through the reference to semiotic compression. It tunes TT so that ST semiotic culture codes become transparent and easily comprehensible for a recipient with a different mentality.

\section{References}

Andreyeva, V. (2009). Text and discourse parameters of literary narration (based on modern German prose).St. Petersburg: the Herzen state pedagogical university.

Bulgakov, M. (1988). Master i Margarita. Moscow: Sovetskaya Literatura.

Bulgakov, M. (2004). The Master and Margarita. Trans. M. Glenny. London: Vintage.

Bulgakov, M. (2008). The Master and Margarita. Trans. H. Aplin. London: Oneworld Classics Ltd.

Bulgakow, M. (2008). Der Meister und Margarita. Trans. T. Reschke. München: Random House GmbH. 
Bulgakow, M. (2012). Der Meister und Margarita. Trans. E. Boener. Norderstedt: Books on Demand.

Burnt by the Sun (1994). Dir. N. Mikhalkov. Studio TRITE, Camera One.

Deutscher, G. (2010). Through the language glass: why the world looks different in other languages: New York: Metropolitan Books.

Garbovskiy, N. (2004). Theory of Translation. Moscow: MSU.

Hatim, B., \& Mason, I. (1990). Discourse and the Translator. London: Longman.

Iser, W. (1996). The Emergence of a Cross-Cultural Discourse: Thomas Carlyle's Sartor Resartus. In S. Budick, \& W. Iser (Eds.), The Translatability of Cultures: Figurations of the Space Between. (pp. 245-264). Stanford: Stanford University Press.

Kabakchi, V. (2001). Practice of English Intercultural Communication. St. Petersburg: Sojuz.

Lambert, J. (2006). Cultural studies, the study of cultures and the question of language: facing / excluding the new millennium In D. Delabastita, L. D'hulst and R. Meylaerts (Eds.) Functional approaches to culture and translation: selected papers (pp. 163-172). Amsterdam: John Benjamins.

Milostivaya, A.I., Marchenko, T.V. (2013). Transformation of Semiotic Culture Codes in English and German Translations of M. Bulgakov's the Master and Margarita World Applied Sciences Journal, 26 (2), 152-156.

Milostivaya, A., \& Marchenko, T. (2014) Mentality of a Soviet Man in the Master and Margarita after M. Bulgakov: English and German Translation Reflection. SKASE Journal of Translation and Interpretation, 7 (1), 41-61.

Prohorov, Yu., \& Sternin I. (2007). Russian: Communicative Behavior. Moscow: Flinta: Nauka.

Sturge, K. (2009). Cultural translation. In M. Baker and G. Saldanha (Eds.), Routledge Encyclopedia of Translation Studies (pp: 67-70). Abingdon: Routledge.

Tver News Agency, (2011), "How to fight rudeness?" [Online] Available: http://tvernews.ru/folk/57286/ (January 25, 2015).

Vorobjev, V. (1997). Linguoculturology: theory and methods. Moscow: Russian University of Friendship of Peoples.

Zauberga, I. (2005). A Knock At The Door: On The Role Of Translated Literature. Cultural Image Making. Across Languages and Cultures, 6 (1), 67-77. 